\title{
Biografia jednostki warunkowana przemianami społecznymi
}

\section{The Biography of an Individual Determined by Social Transformations}

\begin{abstract}
The aim of this article is to show the characteristics of the life of an individual, who grew up in the 1960 and 1970s. On one hand, the situation was determined by the social-political surrounding (overpopulation and poverty, especially in rural communities, mass migration from villages to cities). On the other hand, it was characterised by the unique social experiences of young people, among whom proper development trends were observed within applied educational influences and their results (linearity, the predictability of human life, activity, especially professional, which created the basic circle of the social identities of young people; social and professional promotion). My narrator grew up in a village. His life underwent significant transformations as a result of the development of the sulphur industry.
\end{abstract}

Keywords: biography, narrative interview, trajectory, intentional action, process structures, 'sulphur', city, social transformation.

* Małgorzata Kutyła (ORCID: 00oo-0oo3-2372-8179) - dr nauk społecznych, adiunkt w Akademii Ignatianum w Krakowie; kontakt: malgorzata.kutyla@ignatianum.edu.pl. 
Jednak życie pisze inne scenariusze.

Tutaj, w Tarnobrzegu człowiek młody na dorobku miał możliwość pracy, pracy w godzinach nadliczbowych i mieszkanie przede wszystkim, przede wszystkim mieszkanie.

Cytat pochodzący z wywiadu narracyjnego

połeczeństwo polskie po drugiej wojnie światowej przechodziło gruntowną modernizację. Przeobrażeniom ulegała nie tylko sfera demograficzna, ale również polityczna, ekonomiczna i społeczno-kulturowa. Rozbicie struktury społecznej z okresu dwudziestolecia międzywojennego było efektem nie tylko czasu wojny i okupacji, lecz również wielu procesów, które zachodziły w końcowej fazie działań wojennych, a mianowicie utraty ziem wschodnich i przesunięcia granic na zachodzie kraju wraz z towarzyszącymi im ruchami migracyjnymi'. Jako konsekwencje działań wojennych oraz towarzyszących im modyfikacji społecznej Jacek Wasilewski wskazuje na dwa, w jego opinii, podstawowe skutki społeczne. Jedną z nich stanowiło przerwanie, niekiedy trwałych, karier edukacyjnych i zawodowych wielu milionów jednostek i w konsekwencji obniżenie ich pozycji ekonomicznej. Drugi aspekt dotyczył masowych, częściej przymusowych migracji, co przyczyniało się do wykorzenienia milionów jednostek z ich środowisk lokalnych ${ }^{2}$. W powojennej populacji mieszkańców Polski zdecydowanie przeważała liczba ludności wiejskiej nad miejską oraz kobiet nad mężczyznami. Należy podkreślić, iż członkowie społeczeństwa polskiego nie charakteryzowali się znaczącym kapitałem ludzkim i kulturowym. Większość legitymowała się wykształceniem podstawowym i niepełnym podstawowym. Wśród zjawisk, które charakteryzowały ówczesne społeczeństwo, należy dodać raczej niską przeciętną długość życia (56 lat mężczyźni; 62 lata kobiety) oraz wysoką śmiertelność noworodków (111,2 na 1000 urodzeń). Jednocześnie władza dążyła do przekształcenia społeczeństwa z niewielką dominacją chłopskich gospodarstw w społeczeństwo o wysokim stopniu uprzemysłowienia. Podstawę realizacji tego planu stanowiło masowe kształcenie, przede

1 J. Wasilewski, Formowanie się nowej struktury społecznej, w: Współczesne społeczeństwo polskie. Dynamika zmian, red. J. Wasilewski, Warszawa 2006, s. 52.

2 Tamże, s. 53. 
wszystkim upowszechnienie obowiązku kształcenia na poziomie podstawowym oraz przedłużenie obowiązku szkolnego do 15 roku życia. Drugi wymiar edukacji odbywał się w formie kształcenia dorosłych, obejmujący walkę z analfabetyzmem oraz stworzenie sieci zasadniczych szkół zawodowych, które kształciłyby przyszłą kadrę do pracy w dość intensywnie rozwijających się zakładach przemysłowych ${ }^{3}$. Projekt przebudowy społeczeństwa polskiego po wojnie był oparty na założeniach ideologiczno-politycznych, uwzględniając określone realia ekonomiczne. Model rozwoju społeczno- gospodarczego został oparty na powiększeniu liczby przedstawicieli klasy robotniczej, którzy rekrutowali się przede wszystkim spośród ludności wiejskiej. W tych procesach młodzi mieszkańcy wsi dostrzegali możliwość modyfikacji statusu społecznego, poprzez m.in. kształcenie, możliwość pracy najemnej oraz zamieszkania w mieście.

Miasto jako forma osadnicza, miejsce życia i pracy stanowi jedną z najbardziej fundamentalnych ogniw w ewolucji społecznych warunków życia jednostek. Miasta stanowią przestrzeń społeczną, w której jednostki poprzez zachodzące między nimi interakcje budują wzajemne relacje oraz kreują miejsce. Przestrzeń, jak zauważa Bogdan Jałowiecki, ma zarówno wymiar materialny, jak również symboliczny ${ }^{4}$. Jednostki wytwarzają swoją przestrzeń pełnienia określonych funkcji społecznych, determinując ludzkie zachowania poprzez możliwość zaspokajania swoich potrzeb. Materialny aspekt przestrzeni zasadza się na ilości, jakości oraz dostępności miejsc, które są niezbędne do ludzkiej egzzystencji. Symboliczny wymiar przestrzeni jest określony poprzez emocje, uczucia, wartości, które determinują ludzkie działania. Jednym z klasycznych sposobów rozumienia miasta, odwołujących się do specyficznych, przestrzennie warunkowanych relacji, jakie zachodzą pomiędzy jego użytkownikami, jest podejście charakterystyczne dla socjologii miasta, zwanej szkołą chicagowska ${ }^{5}$. Jego twórca i duchowy przewodnik Robert E. Park sformułował własną koncepcję, w jaki sposób przestrzenny kształt miejskiego środowiska wpływa na jednostki i ich zachowania ${ }^{6}$. Jego uczeń i współzałożyciel szkoły, Louis Wirth, stwierdza, że miasto stanowi specyficzny sposób funkcjonowania ludzi

3 Współczesne społeczeństwo polskie, red. A. Giza A., M. Sikorska, Warszawa 2015, s. 34.

4 B. Jałowiecki, Społeczne wytwarzanie przestrzeni, Warszawa 2010, s. 24.

5 M. Mendel, Pedagogika miejsca wspólnego. Miasto i szkoła, Gdańsk 2017, s. 50.

6 A. Majer, Socjologia i przestrzeń miejska, Warszawa 2010, s. 81. 
w specyficznym miejscu. Jest przestrzenią ściśle zabudowaną i związaną z nieuchronnością sąsiadowania z innymi. Przede wszystkim definiuje je charakterystyczny styl życia określany mianem urbanizmu ${ }^{7}$ Stworzony przez Wirtha model miasta definiowały następujące cechy: wielkość terytorium i populacji; gęstość zaludnienia oraz zróżnicowanie mieszkańców. Te wiążące elementy modelu miasta mają swoje konsekwencje. Wielość powierzchni i ludzi łączy się z wielobarwnością, a jednocześnie praktykowaniem indywidualności; więzi pierwotne częściej zostają zastąpione przez więzi formalne, co skutkuje ograniczonym mechanizmem kontroli społecznej, anonimowością oraz rozdrobnieniem interakcji społecznych. Gęstość zaludnienia mnoży powody do konkurowania, dystansu, poszukiwania kontaktów poza własną zbiorowością. Zróżnicowanie mieszkańców w kontekście rasowym , narodowościowym, religijnym, skutkuje z jednej strony anonimowością i depersonalizacją życia społecznego, z drugiej zaś przełamywaniem barier etnicznych i rasowych, wywołuje potrzebę wzajemnej tolerancji ${ }^{8}$. Styl życia w warunkach miejskich, w zależności od kontekstu, może wywoływać skutki, odczytywane jako pozytywne lub negatywne. Stanowi przede wszystkim społeczne konsekwencje procesów urbanizacji, której towarzyszy modyfikacja systemów wartości, obyczajów, zwyczajów oraz konieczności dostosowania się do wymagań, które niesie ze sobą życie w mieście ${ }^{9}$. Formowanie się tego wyjątkowego stylu życia, zdaniem Marii Mendel, łączy procesy edukacyjne w zakresie konstruowania indywidualnej i zbiorowej tożsamości. Jest ona efektem wysokiego poziomu skoncentrowania ludzkich aktywności w mieście. Autorka ta podkreśla iż, funkcjonowanie w miejskim kręgu oddziaływań uniwersalizuje miejski styl życia, który podlega nieustannej stymulacji. Jest ona pochodną zamieszkiwania w ściśle zabudowanej przestrzeni, sposobem zachowania, działania jednostek i ich wpływu na innych, w rezultacie zmieniając ich aktywności, obyczaje, również ich samych w sensie podmiotowym i tożsamościowym. Nie oznacza to, że wszyscy jej mieszkańcy podzielają jeden styl życia, gdyż w miejski styl życia silnie wpisana jest różnorodnośćc ${ }^{10}$.

7 M. Mendel, Pedagogika miejsca wspólnego, s. 50.

8 A. Majer, Socjologia i przestrzeń miejska, s. 81-82.

9 Tamże, s. 82.

10 M. Mendel, Pedagogika miejsca wspólnego, s. 51. 
Początki rozwoju przemysłu siarkowego w okolicach Tarnobrzega nastąpiły w latach pięćdziesiątych ubiegłego stulecia. Są one nierozerwalnie związane z osobą prof. Tadeusza Pawłowskiego, który w 1953 r. w Mokrzyszowie ${ }^{11}$ „natknął się” na złoża siarki12. Jak wspominał profesor:

Gdy w roku 1953 uzyskałem środki na wykonanie ośmiu odwiertów i już pierwszy okazał się być z siarką, to niektórzy uczeni sugerowali, że trafiłem przypadkiem na pojedyncze gniazdo i że o całym złożu mowy być nie może. [...]. Ale gdy w Mokrzyszowie natknąłem się na siarkę na 80 metrach, Główny Urząd Planowania polecił zintensyfikować poszukiwania. [...]. Uzyskałem pieniądze, lecz postawiono mi warunek, bym do końca roku przedstawił pełną dokumentacje złoża, co można rzec, było warunkiem zabójczym, gdyż do końca roku było półtora miesiąca - owo polecenie otrzymałem dokładnie 15 listopada. [...]. No i zaczęło się ${ }^{13}$.

Rozwój przemysłu siarkowego, i w konsekwencji wzrost pozarolniczego zatrudnienia stał się głównym motorem przeobrażeń społecznych w tym regionie. Przede wszystkim istotnym zmianom w zakresie struktury społecznej, demograficznej, infrastruktury został poddany Tarnobrzeg. Miasto, którego funkcjonowanie rozpoczyna się w 1593 r., do czasu odkrycia złóż siarki było raczej niezmienionym organizmem. Jak stwierdza Tadeusz Zych, w wymiarze historyczno-kulturowym zostało „ukształtowane” przede wszystkim w okresie zaborów, kiedy administracyjnie przynależało do Galicji. W rezultacie Tarnobrzeg kulturowo ciążył w kierunku Krakowa i Lwowa ${ }^{14}$. W okresie dwudziestolecia międzywojennego (podobnie w czasie autonomii galicyjskiej) pełnił funkcję centrum administracji powiatowej, a także lokalnego ośrodka życia gospodarczego. $\mathrm{Z}$ uwagi na brak przemysłu, rozdrobnioną gospodarkę rolną oraz przeludnienie

11 Mokrzyszów - wówczas wioska granicząca bezpośrednio z Tarnobrzegiem, obecnie dzielnica miasta.

12 Odkrycie rudy siarkowej w okolicach Tarnobrzega było konsekwencją badań geologicznych prowadzonych w $1937 \mathrm{r}$. Z uwagi na zagrożenie wojną, powyższe badania były prowadzone celem poszukiwania ważnych gospodarczo surowców, nie tylko siarki. Po zakończeniu wojny, pierwsze odwierty w tym regionie przeprowadził prof. Czarnocki, m.in. w miejscowości Wrzawy. Po jego śmierci w 1951 r., prace geologiczne w tym zakresie kontynuował prof. Pawłowski, J. Michalik, Planowano produkcję siarki z gipsu, „Siarka”, 1990, nr 31, s. 3.

13 Tamże, s. 4-5.

14 T. Zych, Tarnobrzeg pod okupacją niemieckq 1939-1944, Tarnobrzeg 2008, s. 11. 
agrarne zarówno miasto, jak i powiat charakteryzowały się niskim rozwojem społecznym i gospodarczym; miasto - także słabą dynamiką ludnościową. W okresie międzywojnia ludność miasta liczyła od 3 do ponad 5 tysięcy mieszkańców, w tym do lat trzydziestych z przewagą ludności wyznania mojżeszowego ${ }^{15}$. Po zakończeniu działań wojennych, w 1946 r., liczba mieszkańców miasta wynosiła do 4,2 tys. W tym okresie w procesie zmian demograficznych należy wskazać dwie tendencje. W okresie budowy przemysłu siarkowego ludność miasta wynosiła 6,1 tys. (w latach 1955-1960), natomiast znacznie szybszy wzrost mieszkańców miasta zanotowano po 1960 r. (w roku 1975 - 26,8 tys., w 1991 - 49,5 tys.), gdy do eksploatacji oddawano kolejne zakłady produkcyjne i usługowe wraz z rozbudową zaplecza mieszkaniowego dla pracowników podejmujących zatrudnienie ${ }^{16}$. Uruchomienie zakładów przemysłowych spowodowało napływ młodych ludzi do pracy zarówno z okolicznych wiosek, jak i innych części kraju. Tarnobrzeg stawał się dla nich zapleczem mieszkalnym, a także synonimem „lepszego życia”.

Celem prezentowanego artykułu jest ukazanie, jak „siarka” zmieniała biografię pana Józefa. Biografia jednostki rozgrywa się zawsze w pewnych realiach czasoprzestrzennych. Jak stwierdza Danuta Lalak, „życie w ujęciu biograficznym abstrahuje od jego biologicznego wymiaru". Staje się zadaniem ${ }^{17}$. Jednostka jest kreatorem swojego życia. Doświadczenie biograficzne może jawić się jako najbardziej nierozerwalny element jednostkowego rozwoju, pojmowany w kontekście procesu służącego nabywaniu odmiennych doświadczeń, a także ich spożytkowanie (czasami nieświadome) do efektywnej przemiany własnej osoby ${ }^{18}$. Doku-

15 W 1921 r. ludność miasta liczyła ogółem 3169 mieszkańców, w tym ludność żydowska stanowiła 67,7\% ogółu (2 146 tys.). W 1931 r. liczba ludności niewiele wzrosła i wynosiła ogółem 3643 osoby, w tym 61,1\% stanowili Żydzi (2 226). W 1939 r. ludność miasta wynosiła ogółem 5463 osoby, w tym 41,1\% stanowili Żydzi (2 259). J. Gołębiowski, Stosunki społeczno-ekonomiczne w okresie II Rzeczpospolitej, w: Tarnobrzeg, dzieje miasta 1593-1939, red. F. Kiryk, Tarnobrzeg 2005, s. 463.

16 I. Turczyn-Zioło, Z. Zioło, Przemiany demograficzne i społeczne ludności, w: Tarnobrzeg, dzieje miasta 1939-1999, red. F. Kiryk, A. Wójcik-Łużycki, Tarnobrzeg 2010, s. 298.

17 D. Lalak, Biograficzność jako proces kształtowania życia-uczenie się z życia i jego konsekwencje rozwojowe, w: Badanie biografii - źródła, metody, konteksty, red. R. Skrzyniarz, E. Krzewska, W. Zgłobicka-Gierut, Lublin 2014, s. 33.

18 Por. D. Lalak, Życie jako biografia. Podejście biograficzne w perspektywie pedagogicznej, Warszawa 2010, s. 39. 
mentem, na podstawie którego przeprowadzę analizę biografii pana Józefa, jest wywiad narracyjny. Analizy zebranego materiału dokonano w oparciu o struktury procesowe opracowane przez Fritza Schützego: biograficzny plan działania, wzorzec instytucjonalny, trajektorię, biograficzną metamorfozę). Struktury procesowe ukazuję sekwencję doświadczeń jednostki w poszczególnych fazach jej życia: biograficzny plan działania jest tożsamy z perspektywicznym planowaniem własnego życia w zakresie m.in. zdobycia wykształcenia, zawodu; wzorzec instytucjonalny - procesy akceptowane przez jednostkę wskutek oczekiwań społecznych, celów oraz reguł działania; trajektoria - zdarzenia biograficzne sprawiające, iz jednostka pozostaje w sytuacji przymusu, cierpienia, w wyniku, których traci ona kontrolę nad własnym życiem; biograficzna metamorfoza pozytywne przemiany ludzkiego życia związane z pojawieniem się nowych możliwości intencjonalnego działania, które prowadzą do zmian tożsamościowych ${ }^{19}$. Jak stwierdza Marek Prawda, procesualność, w wymiarze indywidualnej biografii pozwala badać jednostkowe losy zarówno jako swoiste formy przebiegu ludzkiego życia (fenomen przebiegu ludzkiego życia), jak i ich uwikłanie w procesy społeczne (fenomen społeczny przez pryzmat biografii) ${ }^{20}$.

Mój narrator decyzję o przyjeździe do Tarnobrzega podjął w sposób zdecydowany. Problemy zdrowotne spowodowały, że miał przewę w uczestnictwie $\mathrm{w}$ zajęciach w szkole wojskowej we Wrocławiu. W międzyczasie wraz z rodziną brał udział w uroczystości weselnej, która miała miejsce, jak sam określał, „gdzieś w okolicach Krosna”. To właśnie w tych „okolicach” po raz pierwszy usłyszał o Tarnobrzegu i Siarkopolu ${ }^{21}$.

19 Por. K. Kaźmierska, Analiza procesu wykorzenienia w narracjach wojennych mieszkańców kresów wschodnich, „Studia Socjologiczne”, 1997, nr 1 (144), s. 60; A. Rokuszewska-Pawełek, Chaos i przymus. Trajektorie wojenne Polaków - analiza biograficzna, Łódź 1997, s 47-50; M. Czyżewski, A. Piotrowski A., Rokuszewska-Pawełęk, Biografia a tożsamość narodowa, Łódź 1997, s. 8; F. Schütze, Presja i wina: wojenne doświadczenia młodego żołnierza niemieckiego, w: Biografia i wojna. Metoda biograficzna w badaniu procesów społecznych. Wybór tekstów, red. R. Dopierała, K. Waniek, Łódź 2016, s. 455-456.

20 K. Każmierska, K. Waniek, Autobiograficzny wywiad narracyjny. Metoda - technika - analiza, Łódź 2020, s. 15.

21 Siarkopol - tak określano Zakłady Przetwórstwa Siarkowego w Machowie-Tarnobrzegu. 


\section{„Ja cały czas marzyłem, żeby jakieś studia skończyć"}

Z opowieści narratora wynika, że ukończył technikum mechanicze. Po ukończeniu szkoły wyjechał do pracy do Wrocławia. Z jego narracji dowiadujemy się, że zamiar podjęcia edukacji na tymże poziomie był efektem jego własnych marzeń. Brak środków finansowych sprawił, iż ten plan nie mógł być w tym momencie realizowany. Jednak te doświadczenia nie przekreśliły jego marzeń. Nie przyczyniły się jednak do zaniechania planów edukacji. Przeciwnie, stały się okazją do podjęcia refleksji celem dokonania określonej zmiany. Narrator był zdeterminowany w swoim działaniu, próbował szukać innych możliwości (,w związku z tym szukałem jakiś takich furtek, a zatem w wojsku szkoła była za darmo"). Z narracji nie dowiadujemy się, czy przestrzeń, w której mógł realizować swoje życiowe zamiary, była przedmiotem jego własnych przemyśleń, czy też ingerowały inne osoby. Jednakże jego doświadczenia biograficzne z tego okresu mają pozytywny charakter. Narrator identyfikuje się z nowym miejscem, jak sam stwierdził: „Wrocław mnie kręcił, ponieważ był miastem przyjaznym dla ludzi. Ludzie między sobą byli życzliwi". Ten sposób narracji pozwala stwierdzić, że narrator pragnął związać z tym miejscem swoje życie osobiste. Ponadto miasto oferowało możliwości, które były atrakcyjne dla młodego człowieka. Narrator wpisał swoje doświadczenia w otaczającą go przestrzeń. Zwracał uwagę zarówno na możliwość pracy zawodowej, jak i edukacji. Z chwilą, gdy pozyskał informację o przekształceniu szkół oficerskich na szkoły wyższe i utworzeniu kompanii desantowo-szturmowej, podjął decyzję o złożeniu dokumentów na uczelnię. Ta forma aktywności wydaje się być zwyczajna, charakterystyczna dla ludzi młodych. Ten rodzaj działalności wpisuje się jednocześnie w zadania, jakie zostały narzucone na jednostkę w tym okresie życia. Świat narratora jest w tym momencie uporządkowany, linearny i przewidywalny. Jego doświadczenia biograficzne zostały wpisane w konkretną przestrzeń. Jego życie było identyfikowane przez przynależność do tej przestrzeni, którą postrzegał w sposób czytelny i komunikatywny, a intencjonalne młodzieńcze plany związane z karierą wojskową spełniły się. Mimo iż, jak podkreślał w swojej opowieści, czas pobytu na tzw. unitarce był okresem bardzo trudnym, w rezultacie zakończył się powodzeniem („To człowieka młodego zawsze kręci, bo to czerwone berety były"). Narrator miał świadomość osiągniętego 
sukcesu. Sukcesu, na który z jednej strony złożyło się pokonanie własnych słabości, z drugiej zaś możliwość uczestnictwa w dalszej edukacji. Sukces ten był dla niego swoistą wartością, ponieważ dawał niejako „przepustkę" do innego, lepszego życia. Z narracji wynika, że rozmówca pochodził z chłopskiej rodziny, o niskim statusie majątkowym i kulturowym („pochodzę z rodziny chłopskiej biednej i niewykształconej"). Zmiana pozycji społecznej mogła dokonać się m.in. poprzez zdobycie wykształcenia. Jego doświadczenia stają się niejako głosem ówczesnego pokolenia, które w większości wywodziło się z rodzin chłopskich („tak w tym okresie co ja każdy chciał być wykształcony”). Wykształcenie dla narratora miało znaczenie zarówno prestiżowe („samo wykształcenie robiło człowieka jakimś tam”), dawało radość, samozadowolenie („wykształcenie dawało dużo satysfakcji), jak i wymiar materialny (oczywiście zawsze się to wiązało z wyższymi zarobkami”). W swojej opowieści narrator jest głównym sprawcą własnych osiągnięć. Trudno w tej narracji dostrzec znaczenie Innych w biografii. Jego życiowe plany, ambicje, aspiracje były raczej skutecznymi działaniami, mającymi na celu świadomą zmianę środowiska rodzinnego i lokalnego. Narrator wiedział, jakie warunki należałoby spełnić, aby swój życiowy pomysł zrealizować. W okresie wczesnej dorosłości jego życiowe zamiary realizowały się w sposób niezakłócony. Nowe doświadczenia dawały mu wiele satysfakcji, gdyż sam był kreatorem swojego losu, umiejętnie realizując postawione cele. Te doświadczenia osobiste (mąż, ojciec), zawodowe (aktywność zawodowa), edukacyjne (uczelnia wojskowa) wyznaczyły linearne ramy jego biografii. Biografii uporządkowanej, zaplanowanej równocześnie kontrolowanej przez samego narratora. Na tym etapie życia, sprawczość związana z kreowaniem własnej egzystencji wydawała się być priorytetową wartością. Bohater umiejętnie i konsekwentnie próbował budować swoją przyszłość. Jednocześnie trudno doszukać się jego uczestnictwa w przymusowych okolicznościach. Z narracji wynika, że bohaterowi towarzyszyło uczucie ciągłej pozytywnej zmiany, ale zmiany zaplanowanej, kontrolowanej, która w konsekwencji miała przyczynić się do satysfakcjonującego życia. Ta przyjemna egzystencja miała być pochodną uporządkowanego życia osobistego i zawodowego, powiązana z pewnością, realizacją własnych pasji i zainteresowań. Aktywna działalność narratora we wspomnianych przestrzeniach życia wydawała się spełniać te warunki. 


\section{„Najgorszy okres unitarny w wojsku przetrzymałem, choć nie do końca, ponieważ zachorowałem"}

Niedyspozycja zdrowotna wydawała się być punktem zwrotnym w biografii narratora. Jak wynika z jego opowieści, problemy zdrowotne spowodowały roczną przerwę w procesie kształcenia. $\mathrm{W}$ tym kontekście wyraźne stało się ukazanie kontrastu między tym zaplanowanym i spełniającym oczekiwania narratora światem a światem nieprzychylnym, zewnętrznym, niezależnym od własnej kontroli. W swojej opowieści narrator nie poświęca wiele uwagi opisowi tego wydarzenia. Aczkolwiek w niedługiej perspektywie to zdarzenie spowodowało istotne zmiany w jego życiu. Brak możliwości uczestnictwa w przestrzeni edukacyjnej przyczynił się do swego rodzaju „zawieszenia” narratora w jego działalności społecznej. Sam niewiele mówił o tym okresie swojego życia. Możemy domniemywać, że był to raczej trudny okres, dlatego też unikał przykrych wspomnień.

$\mathrm{Na}$ tym etapie doświadczeń narratora ważne było to, że nie zaniechał prób w zakresie pozytywnego „poskładania” swojego życia. Sprzyjająca okoliczność, która nadała kierunek zmian najpierw geograficznych, a następnie zawodowych i osobistych, pojawiła się podczas rodzinnego spotkania w okolicach Krosna. Jeden z uczestników uroczystości rodzinnej pracował w Zakładach Przemysłowych „Siarkopol” i podczas rozmowy poinformował narratora o możliwościach materialnych, jakie kształtują się w związku z rozwojem zakładów oraz miasta Tarnobrzega. Przeprowadzona rozmowa przyczyniła się do nieświadomej, choć z perspektywy czasu radykalnej zmiany w życiu narratora. Z narracji wynika, że bohater nie zmienił priorytetów w swoim życiu, zmianie uległo miejsce, w którym życiowe plany miały być realizowane. W opowieści Narratora daje się zauważyć, że jego biograficzne plany nie uległy samozniszczeniu, ale zostały tylko „zawieszone” na czas rekonwalescencji. Z chwilą, gdy pojawiła się „nowa” okoliczność, narrator w sposób zdecydowany, może z odrobiną ryzyka, znowu spróbował realizować swoje marzenia i aspiracje. Warto zauważyć, że w tej części narracji, bohater pierwszy raz opowiada o trudnościach dotyczących pobytu we Wrocławiu (dotyczących otrzymania mieszkania; problemów meldunkowych), które niejako miały chyba w odczucia samego bohatera usprawiedliwić jego decyzję. Aczkolwiek spontaniczny i jednocześnie zdecydowany wyjazd do Tarnobrzega nie oznaczał - jak można odczytać z nar- 
racji - ostatecznego „zerwania kontaktu” z Wrocławiem. Była to raczej kolejna próba, nadzieja, z której można było skorzystać.

\section{„I ja z tego wesela jechałem przez Krosno do Tarnobrzega. Do Wrocławia już nie wróciłem"}

Narrator jest bardzo zdeterminowany, nie waha się podjąć kolejnego wyzwania, przed którym został postawiony. Nie racjonalizuje, pojawiająca się szansa jest silniejsza niż jakiekolwiek obawy i wątpliwości. W swojej opowieści narrator nie przedstawia szeregu argumentów, które potwierdzałyby słuszność jego decyzji. Był jeden najważniejszy motyw, który skłonił narratora do kolejnego działania. Jak sam stwierdza: „o przyjeździe do Tarnobrzega zadecydowała przede wszystkim możliwość otrzymania mieszkania". Właściwie ponownie można odnieść wrażenie, że narrator nadal poszukiwał miejsca, przestrzeni, w której dane mu byłoby realizować własne życiowe plany. Odwoływał się do wcześniejszych zdarzeń i doświadczeń (,ja byłem już żonaty, miałem żonę i dziecko"). W tym miejscu zaczął mówić o sobie „ja”: „miałem”, „pojechałem”. Od tego czasu ponownie zaczął realizować swój biograficzny plan działania, który dał mu możliwość budowania normalnego życia poprzez odsunięcie trajektorii, która zaistniała w efekcie pogorszenia stanu zdrowia. Rekonstruując własne doświadczenia, narrator nie doznawał poczucia, że rozpadł się jego dotychczasowy świat, który skrupulatnie i konsekwentnie kreował. Tymczasowe „bytowanie” w sytuacji granicznej, o ile zapewne w początkowej fazie wyzwalało pewien niepokój i lęk, o tyle w tym momencie stało się nadzieją na zmodyfikowanie aktywności w innej przestrzeni. Poczucie „zapanowania” nad własnym losem oraz odpowiedzialności za rodzinę stało ważnym bodźcem do działania i jednocześnie wyeliminowało z pola widzenia narratora ewentualne obawy przed nieznanym światem. Atrakcyjność oferty sprawiła, że chciał on stawić czoło temu co nieznane. Nowa przestrzeń stała się kolejną, może w tym okresie jedyną szansą realizacji własnej biografii. Zainteresowany możliwościami, jakie otwierały się przed młodymi ludźmi, nie wrócił do Wrocławia, przyjechał do Tarnobrzegu, miasta, a właściwie miasteczka, o którym nie posiadał żadnej wiedzy. Ponadto, jak przyznawał, „nawet nie wiedziałem, gdzie leży ten Tarnobrzeg”. Poznanie nowego świata zawiera się jednocześnie w doświadczeniu zderzeniu z nową przestrzenią oraz konfrontacji z dotychczasowym miejscem: 
Tarnobrzeg zrobił na mnie kiepściutkie wrażenie, dziura po prostu dziura. Jak ojciec później przyjechał, zobaczył, mówi: »Synu, Matko Boska, gdzieś ty przyjechał«. Od stacji kolejowej kiepskie dojście, przystanek PKS w opłakanym stanie. Mieszkałem we Wrocławiu 1,5 roku więc miałem porównanie. Tarnobrzeg to była maleńka mieścinka. Nie myślałem jednak o wyjeździe stąd.

Narrator został sam ze swoją nową rzeczywistością. Jest to cena, jaką musiał zapłacić za potrzebę realizacji swoich planów. W nowej przestrzeni nie miał nikogo, kto służyłby mu pomocą, nie miał społeczności, która stworzyłaby poczucie bezpieczeństwa. Jednakże okoliczności nie degradują jego zamysłu. Poczucie zmiany jakości swego życia jest silniejsze niż ewentualne wyalienowanie. Najprawdopodobniej, o czym zresztą narrator nie wspomina, doświadczył podobnych emocji w momencie osiedlania się we Wrocławiu. Po przyjeździe do Tarnobrzegu sam decyduje o sobie, w tym sensie staje się bardziej dojrzały. Narrator posiada własny plan działania na najbliższe dni. Kieruje się do kopalni Machów w Budowie, gdyż w tym okresie (jesień, koniec lat sześćdziesiątych ubiegłego stulecia) trwała budowa tejże kopalni. Nie będąc przekonanym do złożonej oferty pracy, odrzuca propozycję. Zarządzający kopalnią przyjmują uwagi narratora i składają kolejną propozycję. Jak wspomina narrator: „[...] zaproponowali pracę [...]. W tym Wydziale elegancki kierownik inżynier grzecznie rozmawiał ze mną i dał mi stawkę w wysokości 2100 zł. Taką płacą człowiek był po prostu zainteresowany". W swoich działaniach narrator wykazał się pewnością, był świadomy swojego potencjału, co ułatwiało mu prowadzenie negocjacji. W nowej przestrzeni korzystał z wcześniejszych doświadczeń. Nabyte umiejętności pozwoliły mu na swoistą otwartość i komunikację z nowym otoczeniem. W swoich działaniach polegał na własnych kompetencjach, które cechowała rozwaga, racjonalność, ale jednocześnie wola „poukładania swoich spraw po swojemu”. Narrator wydawał się być przekonanym, że tylko zdroworozsądkowe działania mogą stanowić podstawę do realizacji kolejnych celów. W jego postępowaniu dało się zauważyć pewien porządek: „zapytałem jeszcze, gdzie będę mieszkał”. Uregulowanie spraw związanych z pracą oraz zakwaterowaniem (hotel robotniczy) na tym etapie spełniło jego oczekiwania. Pierwszego wrażenia narratora w nowej przestrzeni nie charakteryzował entuzjazm, proces kształtowania nowej tożsamości był oparty na doświadczeniu trajektorii (obce miejsce, rozłąka z rodziną) w celu realizacji biograficz- 
nego planu działania. Te działania wydawały się mieć charakter zamierzony, były traktowane przez narratora jako etap przejściowy, w perspektywie lepszego życia. Aczkolwiek w tym momencie, w swojej opowieści narrator po raz pierwszy o nowym miejscu mówił „tutaj”, „stąd”, które wydawały się sugerować rozpoczęcie procesu identyfikacji poprzez przynależność do nowej przestrzeni. Początek nowego roku przyniósł kolejne ważne zmiany w życiu narratora, jak również nowej społeczności. Ten czas wydawał się mieć charakter symboliczny. Jak sam wspominał: „[...] w styczniu [...] dostałem pokój rodzinny. W tym czasie akurat Niemcy wyjeżdżali stąd. Uruchamiali koparkę na kopalni Machów. I tam zamieszkałem i tak jestem tutaj do dzisiaj". Te dwa wydarzenia sprawiły, że narrator, z jednej strony scalił swój prywatny świat (przyjazd żony i dziecka), z drugiej zaś w zakładzie pojawiły się nowe perspektywy rozwoju, które w konsekwencji będą oddziaływać na jego życie zawodowe.

\section{„Za rok dostałem mieszkanie, każdy człowiek młody się cieszy”}

Z chwila otrzymania mieszkania sfinalizowało się najważniejsze marzenie narratora. To ono było tym ważnym bodźcem, dzięki któremu przyjechał on do Tarnobrzegu. Stanowiło w jego życiu fundament, na którym realizował swoje kolejne zamierzenia. Zrealizował zadanie dorosłości, zabezpieczył podstawowy byt materialny swojej rodzinie. W tej części narracji daje się zauważyć, że życie osobiste narratora znowu stało się uporządkowane i przewidywalne. Tym samym nastąpił czas, w którym narrator ponownie wrócił do swoich młodzieńczych aspiracji. Miały dla niego istotne znaczenie, gdyż wiązał z nimi określone nadzieje, przede wszystkim na lepszą pracę i lepsze życie. Nadal dążył do osobistego rozwoju. Jak sam stwierdza: „Jak dostałem mieszkanie, zaraz zainteresowałem się studiami wyższymi. [...] To był mój wybór, przełożeni nie utrudniali mi kształcenia". Mając na uwadze dotychczasowe doświadczenia zawodowe, zdecydował się na studia inżynieryjne o specjalności mechanicznej na Politechnice Rzeszowskiej. Rozpoczęcie edukacji zostało poprzedzone kursem przygotowawczym. O trafności tego wyboru zadecydował fakt, iż w tym okresie narrator ostatecznie zamkną sprawę dotyczącą powrotu do struktur wojskowych. Najprawdopodobniej decyzja została poprzedzona rozpoczęciem etapu „zakotwiczenia” w nowej przestrzeni. Proces ten równoważyło powodzenie zarówno w życiu osobistym, jak i zawodowym. Narrator doświadczył 
awansu zawodowego, od stanowiska mistrza, poprzez kierownika działu, głównego mechanika do zastępcy kierownika zakładów chemicznych do spraw technicznych („To już było stanowisko intratne”). Kolejne stopnie kariery zawodowej dodatkowo motywowały jego aktywność. Otrzymał, jak sam stwierdził, „większe pieniądze” i większy zakres obowiązków. Praca zawodowa chociaż dająca możliwość samorealizacji i zadowolenia przynosiła również momenty zwątpienia. W opowieści narrator opowiedział przede wszystkim o dwóch trudnych okolicznościach, które wiązały się z podjęciem wysiłku ukierunkowanego na przeciwdziałanie narzuconym okolicznościom. Tym samym te działania stanowiły niejako próby opanowania sytuacji chaosu, przywróceniem kontroli i jednocześnie ograniczaniem cierpienia. Pierwsza z nich dotyczyła trudnych warunków pracy i związanymi z nimi problemami w zakresie pozyskiwania pracowników. Druga zaś wiązała się z sytuacją, jaka zaistniała w zakładzie pracy po transformacji ustrojowej. Jak wspomina narrator:

U nas w zakładach chemicznych panowały trudne warunki w związku z powyższym trudno było znaleźć dobrych pracowników. W związku z tym pojawiały się pewne zwątpienia, trzeba było ciężko pracować i w sobotę i w niedziele. Nie tylko w czasie pracy, ale również poza kodeksowym czasem pracy, gdyż zdarzały się awarie. To były zakłady chemiczne więc wiadomo że jakieś te zdarzenia nagłe mogły mieć miejsce. Druga uciążliwe składowisko to siarkowodór SO2, SO3, fluor, dawało trochę we znaki. I jeżeli pojawiło się jakieś zwątpienie to tylko na tym punkcie czy człowiek przeżyje.

Należało zatem zapanować nad rzeczywistością, która w pewnym sensie przytłaczała narratora, chociaż nie skutkowała paraliżem. Doświadczenie trajektoryjne stało się niejako wyzwaniem dla narratora i jednocześnie on sam nie pozostawał bierny. Podejmował próby rekrutacji pracowników, które w konsekwencji kończyły się połowicznym powodzeniem. Nie wszyscy nowo zatrudnieni pracownicy spełniali oczekiwania narratora. Mimo problemów związanych z kadrą, jego relacje z pracownikami cechował spokój, rozwaga i pragmatyzm. Jak sam wspominał:

[...] w relacjach z ludźmi, ja dawałem sobie radę, bo mam taki charakter jako człowiek kontaktowy i jakoś tam nigdy nie miałem problemów. Zresztą od początku pracuję z ludźmi, gdyż jako majster to już miałem 20 ludzi, później jako kierownika oddziału miałem 100 ludzi, później 320 ludzi [...]. Nie miałem problemu z ludźmi i może dlatego też te trudne warunki 
pracy nie zniechęcały mnie do pracy. [...] Po prostu myślę że takim nie nerwowym sposobem, dobrą atmosferą, tolerancją, dyscypliną, ci ludzie częściej tu zostawali.

Doświadczenie trajektorii było obecne w biografii narratora również w momencie zmian ustrojowych. Nowa sytuacja stanowiła dla niego kolejne wyzwanie, przed którym nie próbował uciec. Z opowieści wynika, że dla narratora nie była to sytuacja, której nie można byłoby opanować. Znów podjął wysiłek, szereg działań, które miały zapobiec sytuacji, w której znalazł się niezależnie od własnej woli, nie tylko on sam, ale również ludzie, którzy w tym czasie pracowali w zakładzie. Dzięki własnej przedsiębiorczości, a także sieci powiązań społecznych sytuacja została opanowana („i tak to się te nawozy do dzisiaj kręcą i ludzie mają pracę"). Dla narratora ta okoliczność spowodowała niejako „wejście na trajektorię"22, po to tylko, aby w konsekwencji móc realizować określony plan.

\section{„Dzisiaj Tarnobrzeg jest dla mnie wszystkim. I domem, i matką"...}

Biografia mojego narratora wpisuje się kontekst zmian społecznych, jakie dokonywały się w regionie północnego Podkarpacia, w związku z rozwojem przemysłu siarkowego. Dla pokolenia, którego dorosłość kształtowała się w latach sześćdziesiątych ubiegłego stulecia, ten element rozwoju społecznego stanowi ważną część biograficznego doświadczenia. Łączy jednocześnie ujęcie indywidualnego doświadczenia z wymiarem społeczno-kulturowym. Pan Józef rekonstruuje wydarzenia z przeszłości, która jest jego aktywnym udziałem. Przyjazd do Tarnobrzegu stanowił kanwę, na której budował swoje dorosłe życie. Doświadczenia "trajektoryjne" powodowały, że permanentnie podejmował wysiłki celem przeciwdziałania okolicznościom, w jakich się znalazł niezależnie od swojej woli. Jego działania miały charakter intencjonalny, by w konsekwencji ponownie przywrócić kontrolę nad własnym życiem. Analizując losy narratora, można stwierdzić, że jego życiowe aktywności posiadały konstruktywny kierunek. Była to biografia nakierowana na działanie, które narrator postrzegał w kontekście zaradności, przedsiębiorczości i sprawczości. Te wartości stanowiły niejako pod-

22 Zob. K. Kaźmierska, Analiza procesu wykorzenienia w narracjach wojennych mieszkańców kresów wschodnich, „Studia Socjologiczne”, 1997, nr 1 (144), s.68 
stawę finalizacji jego życiowych planów. Realizacja biograficznych planów stała się możliwa dzięki projektowaniu własnej egzystencji w konkretnym miejscu. Z perspektywy własnych doświadczeń narrator przypisuje miastu Tarnobrzeg istotne znaczenie. Zapewniło ciągłość jego indywidualnego i społecznego życia. Postrzega je jako przestrzeń uświadamianą i doświadczaną, w której kształtowała się jego tożsamość. Miasto, w którym narrator, jak sam stwierdził, całe życie w nim spędził: „Tak się stało, że stało się miastem własnym [...]”, zaowocowało poczuciem przynależności, identyczności, zakorzenienia, jednocześnie wspomagało autodefinicję. Miejscem, w którym narrator doświadczył podmiotowej sprawczości, a także wielorakich interakcji zarówno z ludzkimi podmiotami, jak i innymi elementami rzeczywistości.

Streszczenie: Celem referatu jest ukazanie specyfiki życia jednostki, której dorosłe życie kształtowało się w latach sześćdziesiątych i siedemdziesiątych ubiegłego stulecia. Specyfika sytuacji była z jednej strony warunkowana przestrzenią społeczno-polityczną (przeludnienie i ubóstwo zwłaszcza w środowiskach wiejskich; masowa migracja ze wsi do miast). Z drugiej zaś strony - niepowtarzalność doświadczeń socjalizacyjnych ludzi młodych, wśród których najczęściej można zaobserwować pewne prawidłowe tendencje rozwojowe w obrębie stosowanych oddziaływań wychowawczych i ich rezultaty (linearność, przewidywalność ludzkiego życia; aktywność, zwłaszcza zawodowa, która wyznaczała podstawowy krąg społecznych identyfikacji ludzi młodych; awans społeczny i zawodowy). Mój Narrator wychowywał się na wsi. W rezultacie rozwoju przemysłu siarkowego, jego życie uległo istotnym przemianom.

Słowa kluczowe: biografia, wywiad narracyjny, struktury procesowe, „siarka”, miasto, zmiana społeczna.

\section{Bibliografia}

Czyżewski M., Piotrowski A., Rokoszewska-Pawełek A., Biografia a tożsamość narodowa, Łódź 1997.

Gołębiowski J., Stosunki społeczno-ekonomiczne w okresie II Rzeczpospolitej, w: Tarnobrzeg, dzieje miasta 1593-1939, red. F. Kiryk, Tarnobrzeg 2005.

Współczesne społeczeństwo polskie, red. A. Giza, M. Sikorska, Warszawa 2015.

Jałowiecki B., Społeczne wytwarzanie przestrzeni, Warszawa 2010.

Kaźmierska K., Analiza procesu wykorzenienia w narracjach wojennych mieszkańców kresów wschodnich, „Studia Socjologiczne”, 1997, nr 1 (144), s. 57-84. 
Kaźmierska K., Waniek K., Autobiograficzny wywiad narracyjny. Metoda - technika analiza, Łódź 2020.

Lalak D., Biograficzność jako proces kształtowania życia-uczenie się z życia i jego konsekwencje rozwojowe, w: Badanie biografii - źródła, metody, konteksty, red. R. Skrzyniarz, E. Krzewska, W. Zgłobicka-Gierut, Lublin 2014, s. 33-52.

Lalak D., Życie jako biografia. Podejście biograficzne $w$ perspektywie pedagogicznej, Warszawa 2010.

Majer A., Socjologia i przestrzeń miejska, Warszawa 2010

Mendel M., Pedagogika miejsca wspólnego. Miasto i szkoła, Gdańsk 2017.

Michalik J., Planowano produkcję siarki z gipsu, „Siarka”, 1990, nr 31.

Rokuszewska-Pawełęk A., Chaos i przymus. Trajektorie wojenne Polaków-analiza biograficzna, Łódź 1997.

Schütze F., Presja i wina: wojenne doświadczenia młodego żołnierza niemieckiego, w: Biografia i wojna. Metoda biograficzna w badaniu procesów społecznych. Wybór tekstów, red. R. Dopierała, K. Waniek, Łódź 2016.

Turczyn-Zioło I., Zioło Z., Przemiany demograficzne i społeczne ludności, w: Tarnobrzeg, dzieje miasta 1939-1999, red. F. Kiryk, A. Wójcik-Łużycki, Tarnobrzeg 2010.

Zych T., Tarnobrzeg pod okupacją niemiecka 1939-1944, Tarnobrzeg 2008.

Wasilewski J., Formowanie się nowej struktury społecznej, w: Współczesne społeczeństwo polskie. Dynamika zmian, red. J. Wasilewski, Warszawa 2006. 